This is a pre-print version of an article published in Journal of Ethnic and Migration Studies, doi: 10.1080/1369183X.2016.1238905

\title{
The Role of Religion in Protecting Older Romanian Migrants from Loneliness
}

\author{
RUXANDRA OANA CIOBANU \\ Center for the Interdisciplinary Study of Gerontology and Vulnerability, University of \\ Geneva, Switzerland \\ TINEKE FOKKEMA
}

Netherlands Interdisciplinary Demographic Institute (NIDI-KNAW), University of Groningen and Erasmus University Rotterdam, the Netherlands 


\begin{abstract}
This article explores qualitatively how and to what extent religion protects older Romanian migrants from loneliness. The analysis is based on fieldwork research in two Swiss cantons and in neighbouring France among 30 Romanian migrants aged 57+. The sample is heterogeneous, made up of persons who fled the communist regime in their youth and others who migrated later in life for work or to be with their families. The fieldwork research points towards a population that is coping successfully with migration and other challenges, many of whom did not report feelings of loneliness. In an increasingly laic occidental world, many of the Romanian participants in our research appear to be religious and go to church; this often protects them from loneliness, whether they migrated 30 years or seven months ago. The article concludes with study limitations, implications, and directions for further research.
\end{abstract}

Key words: Older migrants, Loneliness, Social networks, Coping strategies, Religion 


\section{The Role of Religion in Protecting Older Romanian Migrants from Loneliness}

\section{Introduction}

This article explores qualitatively the relationship between religion and loneliness among older Romanian migrants in Switzerland who either fled communism in their youth or migrated later in life for work or family reasons. Based on data from in-depth interviews with 30 Romanian migrants aged 57+, we address the following question: How and to what extent does religion protect older Romanian migrants from loneliness?

Our study extends and contributes to the existing literature in two ways. Firstly, we examined the role of religion in a cultural setting that differs substantially from previous studies. By far, most studies on the religion-health relationship have focused on native older populations and to a lesser extent on older ethnic minorities in the United States (as an exception, see Ahmadi Lewin and Thomas 2001). To the best of our knowledge, this study is the first of its kind to include older Romanian migrants. At first glance, like many other older persons living outside their home country, they might be particularly susceptible to loneliness due to their vulnerable situation in terms of health, wealth and social status (de Jong Gierveld, van der Pas, and Keating 2015; Fokkema and Naderi 2013; Victor, Burholt, and Martin 2012). However, given the relatively high level of religiosity among Romanian migrants, religion may be protecting them from mild or severe loneliness. Secondly, the migrant groups to which Romanians pertain have not been studied much, let alone the impact of religion on loneliness. The literature on older migrants in Switzerland (Bolzman et al. 2004, 2008; Bolzman, Fibbi, and Vial 2006; Guillon et al. 2001) focuses largely on labour migrants who arrived after World War II and are ageing in place or developing transnational mobilities between their home countries and Switzerland. Other groups of older migrants - such as (former) political refugees ageing in place, late-in-life labour migrants or older migrants joining their family (the subjects of our study) - have received very little attention both in the Swiss literature and more broadly in the literature on older migrants (Bolzman and Scott 2010; King et al. 2014; King and Vullnetari 2006; Nedelcu 2009; Soulard 2013). The particularity of older former political refugees - as opposed to other flows of migrants who are ageing in place - is the context of their migration and arrival abroad. These persons migrated to Switzerland at a time when upon arrival they were receiving refugee status quite 
fast, and they had full rights except for voting and male military service. By contrast, late-life migrants experience more difficulties integrating and nostalgia for their home country. Moreover, they tend to be highly dependent on their children in the host society in terms of finances, housing, social life and prospects to return, all of which undermine their well-being (Ip, Lui, and Chui 2007; King et al. 2014; Park and Kim 2013).

The article is structured in five parts. The first part reviews the theoretical concepts at the core of this article - loneliness and religion as a coping strategy in the context of migration. The second part gives an overview of the context of Romanian migration to Switzerland and Romanians' religiosity. The third part presents the research methodology used for the data collection and the sample. The fourth part moves on to the results, discussing the different roles of the church in protecting older Romanian migrants from loneliness, and the discussion and conclusion returns to the question set forth in the introduction, ending with future research directions and practical implications.

\section{Theoretical considerations: Loneliness and religion as a coping strategy in the context of migration}

Loneliness - commonly defined as unpleasant feelings arising when one perceives a discrepancy between desired and actual number and quality of social relations (Perlman and Peplau 1981) - has been a topic of intensive research for decades. Nearly all studies have looked at native-born populations, focusing more specifically on older populations. Only recently has there been a growing interest in the experience of loneliness among older migrants. Apart from an increasing number of older adults with a migration background, this research interest is driven by the premise that older migrants are particularly vulnerable to suffering from loneliness because they face a double-edged sword (Dowd and Bengtson 1978). In addition to losing a partner and friends, and health and mobility problems due to ageing, the literature suggests various migration-related factors that lead to significant barriers and constraints on the social activities and networks of older migrants, like limited mastery of the host country language, financial concerns, discrimination and cultural clashes.

Findings of the limited empirical work so far almost unanimously confirm older migrants' social vulnerability. Regardless of ethnicity and host country, quantitative studies show that, on average, older migrants are more likely to be lonely than their native peers (de Jong Gierveld et al. 2015; Fokkema and Naderi 2013; Victor et al. 2012; Wu and Penning 2015). The qualitative studies, which focus predominantly on those who migrated in later life to live with their offspring (the zero generation), portray older migrants' isolated social 
situation as owing to a lack of knowledge and resources (language skills, income) to function independently in the new country (Cela and Fokkema 2016; Choudhry 2001; Dong et al. 2012; Ip et al. 2007; King et al. 2014; Lee 2007; Park and Kim 2013; Treas and Mazumdar 2002). Most researchers have no regard for diversity and fluidity though, which risks to problematise and stigmatise the older migrant group as a whole (for an excellent discussion on this issue, see the introduction by Zubair and Norris (2015) and other articles in the Special Issue of Ageing \& Society). Because heterogeneity and inequalities between and within older migrant groups as well as changes in circumstances over the life course have been ignored, knowledge is lacking about when and how it is that older migrants succeed in avoiding or alleviating feelings of loneliness, either by themselves or with the help of others.

Religion, the focus of this article, can be assumed to play an important role in loneliness prevention and reduction. An impressive number of quantitative and qualitative crosssectional studies for the general (older) population at least hint at it, showing a positive association between religion and a broad array of physical and mental health issues (see Koenig, McCullough, and Larson 2001 for a comprehensive review of this literature), including low levels of loneliness (Gray 2009; Johnson and Mullins 1989; Kobayashi, Cloutier-Fisher, and Roth 2009; Rote, Hill, and Ellison 2013). Moreover, given this complex multidimensional phenomenon, there are a variety of pathways through which religion may help older people deal with feelings of loneliness, covering problem-focused as well as emotion-focused approaches (Ellison and Levin 1998; Pargament 1997). Researchers usually distinguish two broad dimensions: intrinsic and extrinsic religiosity. Intrinsic religiosity includes private devotional activities like praying, bible reading, and listening to or watching religious programs, as well as personal beliefs in God and the afterlife. These individual practices and beliefs can act as a source of strength and comfort in managing or coping with negative emotions of loss and limitations people experience in old age as well as the normal challenges of ageing, and offer meaning for interpreting these experiences, and hope for the future. Extrinsic religiosity comprises attendance of church meetings and services, and volunteer or group activities associated with religion. Regular involvement in organised religious activities provides an important social context in which friendships with fellow church members and supportive exchanges can be built and strengthened (Krause 2008; Krause and Wulff 2005; Rote et al. 2013). Organisational religious involvement can also give people a sense of belonging to a community, feeling valued and protected, being important in other people's lives and being 'at home'. 
While these functions of religion might be particularly helpful for coping with migratory challenges, at least for some older migrants, the scarcity of research on their protective role against loneliness is surprising. Occasionally, the beneficial impact of religion is spotted coincidentally (Choudhry 2001; Silveira and Allebeck 2001; see also the articles of Horn and Patzelt in this Special Issue). The few exceptions that explicitly examine the link between religion and loneliness are amongst Asian older migrants in the U.S., clearly showing that both intrinsic and extrinsic religiosity counterbalance migration-related grief and losses for a non-negligible proportion of these individuals (Kim 2013; Roh, Lee, and Yoon 2013; Zhang and Zhan 2009). To our knowledge, there is no study that explicitly addresses the contribution of religion to the reduction or prevention of loneliness among older migrants in Europe, particularly older Romanians.

\section{Migration history and religiosity of older Romanians in Switzerland}

Romania was under communism from 1947 to 1989. During that period, travelling abroad was highly restricted and few people, mainly from the communist nomenclature, had the privilege of holding a passport. Emigration was only in one direction: those who fled had to cut ties to Romania and could not return (Michalon and Nedelcu 2010). These persons applied for political asylum in Western Europe and North America. One of the countries that hosted Romanian refugees was Switzerland. Worth mentioning is that some Romanians reported being asked to give up their Romanian citizenship either before emigrating or later on in Switzerland. Hence the number of Romanians who applied for political asylum abroad was under-declared. This notwithstanding, Romanians - particularly in Geneva - represented an important group whose presence in the canton dates back to 1974 (Musillo and Bolzman 1986).

The fall of communism was followed by an increase in economic migration to various countries. Among labour migrants there are also people who migrate late in life for work reasons, and age in place. With the increased economic migration, another group of migrants emerged: the zero generation, i.e. elderly parents who travel abroad for short or long stays to be closer to their adult migrant children and grandchildren (King et al. 2014; Nedelcu 2009). They do not generally intend to settle abroad, and have strong ties to Romania. Others migrate through family reunification, following their partners - either Swiss or Romanian.

Because of their different moment of arrival, status and motive for emigration, the older Romanian migrant group in Switzerland is heterogeneous. It is particularly difficult to provide statistics on the number of older Romanians because many of them, especially former 
refugees, have acquired the Swiss nationality and consequently 'disappear' from the statistical radar. We do know that in 1990, out of the total number of recognised refugees, $47 \%$ were from South-Eastern Europe and that there were 1401 recognised Romanian refugees in Switzerland (674 men and 727 women). In this context, Romania takes fourth place after former Czechoslovakia (with 3621 recognised refugees), Poland (2824) and Hungary (2520) (PETRA, Federal Office for Statistics, Switzerland). In 2012 there were a total of 234 (159 women and 75 men) Romanians aged 60+ who were permanent residents of Switzerland; 64 of them (44 women and 20 men) resided in the canton of Vaud and 50 (33 women and 17 men) in the canton of Geneva (Federal Office of Statistics, Switzerland), the two cantons where our fieldwork was conducted.

During the communist regime religion was prohibited in Romanian public life (Voicu, Fosztó, and Gog 2009), yet people continued to practice discreetly. The post-communist transition was marked by a religious revival (Voicu and Constantin 2012) and twenty years after the fall of communism, 'Romania ranks among the most religious countries of contemporary Europe' (Voicu et al. 2009, 3). Orthodoxy is the main religion in Romania, accounting in the 2011 census for $81 \%$ of the population, followed to a lesser extent by Roman and Greek Catholicism, various other Protestant and neo-Protestant denominations, and a small Muslim community. The church has played an important role in labour emigration from Romania after the fall of communism in 1989 (Ciobanu 2009; Sandu 2005), with people forming social networks around the various denominations. In the Swiss case too, Hainard and Hämmerli $(2011,1)$ show that 'Eastern Orthodox parishes can play a role in their members' integration at the destination'. In Geneva there are three Orthodox churches and one neo-Protestant gathering, and in the canton of Vaud one Orthodox church, all attended mainly by Romanians. All priests are Romanian and the religious ceremonies are mainly in Romanian with occasional use of French.

\section{Research methodology}

The analysis is based on fieldwork research in the Swiss cantons of Geneva and Vaud and in neighbouring France. Although we study older migrants in Switzerland, the geopolitical context led us to do interviews in France too, as many people work in Switzerland and live in French border towns. These are to some extent 'dormitory towns', and Romanians living there have strong ties to Geneva: they attend the Romanian Orthodox churches in Geneva, work in Switzerland, and some go to see doctors in Geneva. Especially there we encountered zero- 
generation Romanians who migrated to be closer to their adult migrant children and grandchildren.

This study is part of a larger project on the integration of older Romanian migrants in Switzerland and transnational ties to Romania. For the data collection on the topic of loneliness we used a semi-structured questionnaire with five topics: the De Jong Gierveld 11item loneliness scale, the concept of loneliness, loneliness in the Romanian community, individual loneliness - past, present and future - and satisfaction with one's life. The loneliness scale is a widely used valid and reliable instrument for measuring loneliness; based on an individual's total score, ranging from 0 to 11 , participants can be classified into four categories: not lonely (score 0-2), moderately lonely (3-8), severely lonely (9-10), and very severely lonely (11) (de Jong Gierveld and van Tilburg 1999). During the interviews participants spontaneously referred to religion, as we had not included religion-related questions in the guideline. When there was no mention of religion, the interviewer enquired if they attended church, and in such cases people said that they went to church very rarely.

The fieldwork was conducted between April 2013 and January 2014. The first author conducted 27 in-depth interviews with Romanian individual migrants (24) and couple migrants (3) aged 57+. All interviews were done in Romanian, although at times some participants also spoke in French. The average duration of the interviews on the topic of loneliness was 40 minutes. In Geneva thirteen interviews were conducted, in Vaud twelve interviews and in France two. The respondents were identified through different institutions in which Romanians are involved (all institutional channels accounting for twelve respondents), through recommendations of colleagues and friends (nine respondents), or using the snowballing technique (six respondents). The interviews were conducted at respondents' homes (17), at the first author's workplace (5), in public spaces, usually cafes (4), and at a respondent's workplace (1).

In terms of sample composition (see Table 1), the interviews were conducted with seventeen women, seven men and three families (three men and women), adding up to a total of 30 respondents. Family interviews involved both partners simultaneously and respondents answered completing each other. Regarding marital status, 22 respondents were married, two were divorced and six were widowed. Regarding age groups, four respondents were aged between 57 and 64, eighteen respondents between 65 and 74, and eight over 75. The largest number of respondents corresponding to 21 interviews arrived during communism and aged in place. The remaining respondents came to Switzerland/neighbouring France after their retirement in Romania with the aim of providing care for their grandchildren and/or being 
closer to their family, or migrated through family reunification, joining their spouses, and have aged in place; only one respondent came for work later in life.

Important distinguishing variables between participants are duration of time spent in Switzerland and intentions to settle or return to Romania. The average duration of residence in Switzerland (and France) was 29 years. The longest duration was 42 years and the shortest seven months. The average duration for those who came during communism was 34.6 years and for the other respondents 6.5 years. Those who left Romania during communism do not have any intention to return. Likewise, individuals who migrated late in life for work or followed their spouses abroad intend to remain in Switzerland. By contrast, migrants who are in Switzerland in order to be closer to their adult children and help raise their grandchildren aim to return once their 'duty' abroad finishes, and rejoice at any possibility to travel to Romania.

Regarding level of education and knowledge of French, all but two respondents completed at least high school; the majority held college or university degrees. Most respondents worked in jobs at their own educational level and most reported speaking French, apart from the zero generation who did not speak French and some recent migrants who spoke little French. There are no clear differences in church attendance between recent migrants and those who arrived a long time ago: both groups include frequent, occasional and infrequent churchgoers.

The interviews were transcribed and translated into English by the first author, who is a native Romanian. Next, she did a content analysis of the interviews. The themes of analysis emerged from the interviews based on their recurrence frequency. Religion was not an explicit question in the interview guideline, yet respondents spoke about it at large. All participants were given pseudonyms to assure their confidentiality.

$<$ Table 1 about here >

\section{Results}

\section{Loneliness}

Based on participants' answers to the 11-item loneliness scale and to the interview in general, in Table 1 we convey both the loneliness categories based on the scale scores and participants' expressions during the interviews about being lonely, which are mostly similar and point to generally low levels of loneliness. Recent migrants, however, report being moderately lonely or lonely more often than those who arrived a long time ago. Despite the 
sensitivity of this topic, participants were rather open to talk about it. Noteworthy is the fact that when responded to the loneliness questions, participants always asked if having somebody to rely on refers to the home country or to Switzerland. Although participants were not considering permanent or long-term return to Romania - apart from the zero generation most still have close ties and exchanges with family and friends back in Romania.

Many participants, particularly former refugees, clearly differentiate aloneness from loneliness. They assessed themselves as solitary persons but not feeling lonely, even expressing a preference for solitude. They like to be on their own, whether single or as a couple. In other words, because of a rather high loneliness threshold (Johnson and Mullins 1987) there is no perceived discrepancy between what they have and what they prefer in terms of social contacts. As Florina (F, 72, former refugee, Geneva), a widow whose mother who followed her to Switzerland passed away, says: 'I am a solitary person by birth and am not afraid of it. I feel the need to be alone and not be bothered by anybody.... Being with myself, to work, to meditate'. Marcu and Mioara (M, 72, F, 66, former refugees, Vaud) are an example of a couple that does not suffer from loneliness. They have no children, Marcu's brother lives in Romania and Mioara's sister lived in Greece. They are not really churchgoers and rather enjoy being on their own.

Many refugees' preference for being alone can be explained by their experiences under communism and their migration history. This migration needs to be understood as a separation from Romania under the most adverse conditions. Some individuals had problems with the Romanian security services, which made them seek refuge abroad. For others it was a matter of giving their children a chance or wanting to escape a totalitarian system. Either way, fleeing Romania, arriving in a new country sometimes on their own, and not knowing if they could ever return to their home country required a lot of mental strength. Living under communism not only has a significant bearing on people's mentality but also on one's lack of trust in others. People surrounded themselves with those they really trusted and sometimes this meant only the family. Moreover, following the arrival in Switzerland many rumours circulated that some people were informants for the security services, so their company was sometimes avoided. When enquiring during interviews about social interactions and fear before and soon after arriving in Switzerland, people generally said that they had relations with other Romanians, but these were often superficial and political discussions were avoided. The fall of communism in 1989 has not changed relations between Romanians. The persistent lack of confidence in others keep people cautious, hence they mainly rely on themselves and their close ones. 


\section{The different protective roles of religion}

Four functions of religion stood out from the fieldwork research: the protective element of faith, the feeling of belonging to a bigger group, the church as a place for encounters and establishing social ties, and the exchange of support among churchgoers.

\section{Faith as a shielding element}

A recurrent element in several interviews was the presence of God as 'best friend' in migrants' lives and the role of praying to deal with difficult situations. Costin (M, 67, former refugee, Geneva), who is very active in church activities and is still pursuing his life passion for art, underlines his belief in God: 'I am not scared of loneliness, because I will never be lonely. As long as I have God, I will not be lonely. And as long as I can draw, I am not lonely'. Ileana (F, 70, former refugee, Vaud) spoke of how she overcame her husband's death, not by going to a psychiatrist as suggested by her children and friends, but by praying:

In life I was disappointed by friends. Friend is only God. He knows me, I pray, I tell him my sorrow and He understands me. Somebody else.... I don't know who would understand me. The children? They have their problems, they have meetings in court [one daughter is a lawyer], they have school [the other daughter has children], so it is me and the praying book and I feel very good.

Faith is important also for zero-generation migrants:

For me this [faith] has been the only pillar.... hang on to God, to his hand.... Someone wrote on the internet [...] the only thing someone can do in the night of life is to take God by the hand, and He will take you, because He teaches you. [...] I do not have any other support; I've never had any other support. We were always alone; alone I mean, us the family, but we always succeeded only through God. (Viviana, F, 61, zero generation, France)

These two quotes provide insights into the way people incorporate their belief in God into everyday life and how faith protects them and helps them overcome difficult moments. It also shows the lack of trust in people due to life under communism and the attitude to count on themselves and 'Father in Heaven' (M, 67, former refugee, Geneva). Marcel (M, 92, former 
refugee, Vaud), an ex-doctor who invested a lot in his professional career, goes even further, stating that: 'They say in Orthodoxy that if you have friends here, you do not have God anymore, so I prefer solitude so that my relations to God are not disturbed, so that the neighbour is not impeding me from praying to God'.

\section{Feeling of belonging by attending church ceremonies}

Attending religious services creates feelings of belonging. Through language, rites and familiar songs these ceremonies recreate a familiar environment. They are the constant element in the life of these older Romanians that existed both before and after their experience of migration. Because in Romania the largest part of the population is Orthodox, religion overlaps to some extent with the national identity, hence the church recreates a safe and identifiable milieu. Florina (F, 73, former refugee, Geneva) speaks about her old feelings of loneliness and how she overcame them through a combination of getting involved in activities and going to church:

I had a period when I felt very lonely because I couldn't communicate. I was mute because of the surgery. [...] This lasted 6-7 months. I was isolated, I didn't even have a TV set, I was in Paris among strangers. It was hard. But, how can I say, it was good because it was in the spring, I arrived in February, they did the surgery and it was in the spring, in April, when there were the preparations for Easter, there were the religious evening celebrations and I was going, mute or not, I was there [at church]. Plus I saw, I was leaving the house at 8 and coming back at 5 when they were closing the Louvre, for 5 months I saw the Louvre step by step, I saw the neighbourhoods of Paris, a neighbourhood each week, I read, I knew to go and see.... the emptiness was filled, I was coming back in the evening tired. And this emptiness and loneliness were filled because I was living alone.

Ilona (F, 65, zero generation, Geneva) tells how she found out about the Romanian Orthodox churches, one through Romanian acquaintances and another one via the internet. She spoke about the church she is attending: 'I feel as if I am in Romania when I'm there. How can I tell you, I say I am in Romania when I'm there'. 


\section{The church as social platform}

The church constitutes an important place for meeting people and for gathering, establishing and strengthening ties. Mihai (M, 67, former refugee, Geneva) refers to Sunday religious gatherings as well as to social events organised by the Community of Romanians in Switzerland. He comments on the social role of the church in Romanian villages and how the church in Geneva fulfils the same role:

Like in the Romanian villages, our church is a place of social gathering, it has a social role. There are people who come there, they make connections, for example we have two annual parties, on June $8^{\text {th }}$ in the courtyard of the church and another in a room in Chêne-Bourg, which is always enormous, also with cultural surprises, so to speak.

At one Romanian Orthodox church, former refugees organise two yearly parties together with young, recently arrived labour migrants. At another church, all those attending spend time together, eating something and having a drink after Sunday mass. The church thus constitutes a place for encounters. Long-lasting relationships are also established through channels other than the church, yet part of the church's social role is the opportunity it provides for people to form spontaneous, albeit superficial acquaintances while attending religious services. This is mainly the case for recently arrived migrants, whose social interactions with other Romanians are primarily bound to the time and place of Sunday mass or other church social activities. To some extent we can say that their interactions have not had the time to solidify, and some migrants just do not have the time to get involved in church activities. These two specific groups of older migrants - recent arrivals and Romanians who have resided in Switzerland for decades now - interact only occasionally and not many strong social ties are established between them yet.

Maria (F, 61, zero generation, France) speaks first about the social role of the church as a place to meet people and make friends, even though strong established ties may be missing. Next, she refers to the disadvantages of being busy - as we will see below, presented by other participants as a way of coping with loneliness - leaving little time for lonely Romanians:

Here, we are alone, we are truly alone. It was by chance that we have some acquaintances that we met at the church and we developed friendships. But we meet them there and that's all.... We see them during events, once a week. There 
are two, three families with whom we meet for Easter, Christmas, children's birthdays, but this happens two, three times a year.

When asked why Romanians feel lonely, she explains:

The lack of time, I think. The families I've met, they each have their problems, they leave in the morning, they come back in the evening, everybody has their families, their children, they gather in the evening and the next day they start all over again. So the lack of time.

\section{Receiving and giving support}

The church creates a hub of persons who provide and receive emotional and practical support. Priests and churchgoers take over safeguarding roles by initiating or mediating contacts between persons, identifying vulnerable individuals, and driving the elderly and the sick to medical appointments. Looking particularly at those Romanians who arrived in the 1970s, this is an increasingly older population, many of whom have already passed away and a few are in nursing homes. The interviews do show however that still-active members visit those in nursing homes, and that they call each other. The priests visit the elderly - in retirement homes, in hospitals or at home - and share information with younger members of the community who have time for this. Hence not only the church itself plays a protective role, but people involved in church activities also take over roles of social control and support.

Gina (F, 65, former refugee, Geneva) tells that she felt very lonely upon arriving in Switzerland, after being used to be surrounded by a large family. She found emotional support in her religious network:

I got in touch with them because I didn't have anyone else. They came and their daughter took me to the hospital to see a doctor until I got better. And then at the French church there were some families - as my husband said - a man who knew Romanians, who had lived in Romania in the old days, when he was young, with his parents who were working there because there were also times like this when people went to work in Romania. He and his son, they helped us a lot with a kind word, with moral support, in various ways. 
The supporting role of the church as an institution is present among Evangelical Romanians in Geneva too. Gina (F, 65, former refugee, Geneva) and her husband are among the oldest in the Geneva neo-Protestant community. Moreover, he was a pastor for a small Roma community in France. Older and more established members of the community appear to take over the role of identifying and protecting the vulnerable - which also includes the lonely:

There are people who are lonely. We try to find out who they are, invite them, make acquaintances. [...] But we amongst ourselves [neo-protestants], not to brag, we look after each other. There is a family now, and she also started working more intensively and I told my husband that we need to call them, to invite them because they haven't come over for a long time, and see how they are.

\section{Religion is not always the key to success}

Despite all the wealth of evidence, there is not always a direct connection between religion and loneliness. We identified three such situations: some believers do experience loneliness; some non-believers do not feel lonely; and some believers do not feel lonely but factors other than religion help them cope with loneliness.

\section{Causes of loneliness}

Notwithstanding the protective role of religion, some participants experience feelings of loneliness due to other circumstances or are aware of being at risk of becoming moderately or severely lonely in the future. From the interviews it appeared that Romanians consider as main causes for loneliness, in general and sometimes also for themselves, having migrated and consequently the absence of family and friends abroad; health and mobility problems; and probably most importantly, the death of a spouse or other close persons.

Migration separates families and can put people in situations of feeling lonely. Maria (F, 61, zero generation, France) arrived only recently to help her daughter, who migrated with her family. Maria's son-in-law got a job in Geneva, and the family settled in a small French town, less than $10 \mathrm{~km}$ from Geneva. Maria's daughter felt very much alone caring for her small baby and expecting another one while her husband travelled a lot for work, so Maria left her own older mother and husband in Romania and came to France. The two women's lives revolve around caring for the two children. Despite keeping busy, both mother and daughter have been feeling lonely. Maria contemplates returning to Romania once her grandchildren go 
to school. She realises, however, that returning to Romania may not be the solution to loneliness due to the distance from her two adult migrant children:

My son has a permanent position in France and he bought a flat, and said they would not come back to Romania. As for them [the daughter's family], it is not yet certain. And of course if the children are far away I will feel lonely.

The majority of our participants are relatively young and are not the ones currently experiencing severe health and mobility problems. They are however aware of the high likelihood of these problems befalling them in the near future, and of this being an important risk factor for loneliness. Apart from being dependent on the help of others, poor health and mobility reduce the extent to which they can go out and participate in social activities. In this respect Barbu (M, 72, former refugee, Geneva) speaks about a colleague who was a doctor and 'quite popular', 'had his own practice, a lot of clients and social relations' but who is likely to suffer from loneliness due to his physical handicap because 'when one is sick and looks bad, one does not see other persons'. Roza (F, 83, former refugee, Geneva) gives the example of her lonely friend who has Parkinson's disease and never ventures further away from her home than 'her neighbourhood to walk the dog'.

Even though some overcome widowhood feelings of loneliness, usually persons whose spouses have died appear to be particularly vulnerable to loneliness. Despite the oftenmentioned preference for solitude, even participants who asserted that loneliness depends on one's character and will can imagine themselves feeling lonely if their partner died: '... if my wife disappears, for sure. I would not be able to marry again. It would be a terrible thing for me' (Mihai, M, 76, former refugee, Geneva). The death of other family members and friends leaves similar voids:

Marcu: $[\ldots]$ there are the holidays that are spent with family and since the sisterin-law died....

Mioara: A lot changed from that moment.

Marcu: And we compensate, we have friends in the US, we went to visit them. It was a kick for us. We could have imagined anything... but not that she... Mioara: It was horrible.

Marcu: And this changed our habits when spending holidays, Christmas and Easter. 
Mioara: It is a huge absence for me.... I cannot make myself believe it. (Marcu, M, 72 and Mioara, F, 66, former refugees, Vaud)

\section{Other coping styles}

Religion is not the only way for our participants to overcome or prevent loneliness. Moreover, as Table 1 shows, none of the participants who never or rarely attend church expressed loneliness feelings. Being busy appears to be the main alternative coping strategy. Through distraction with other activities, one does not have the time to constantly think about the loneliness problem, if any. Although geographical proximity of the extended family is a common denominator in this respect, striking differences between long-settled and recent migrants are observed in the way they spend their time. Those who have lived in Switzerland for many years are generally well integrated into Swiss society, economically and socially speaking. They usually take an active role in grandparenting - bringing the grandchildren to school and activities, cooking for them - but their adult children may not rely on them entirely or at all to assist them with the grandchildren, and they also use institutionalised child care or have nannies. Some grandparents spend time with their grandchildren a few hours a day or occasionally, but they can dedicate the rest of their time to their hobbies, volunteer activities, and social life outside of the family. By contrast, recent migrants' approach to not feeling lonely is to fill their time with home chores. This applies not only to late-in-life labour migrants but also to zero-generation migrants. As Viviana (F, 61, zero generation, France) tells, she has 'come to work', referring to caring for her grandchildren, her main and even only activity. Somewhat paradoxically, because of their duties they lack the time to build a social network outside the immediate family context. Not speaking French, the children's busy work schedule and the intention to return to Romania when their grandchildren go to school are other oft-cited causes for their narrow social circle. Their reactions to this socially vulnerable situation are not in terms of being afraid of becoming lonely, but rather: 'I will not let myself be lonely. I will not let myself let go. I will find an activity. I will not stay alone, because I do not want to. I always want to be with somebody' (Ilona, F, 65, zero generation, Geneva). Similarly, Fabiana (F, 57, late-in-life labour migrant, Geneva) says: 'I don't think [I will feel lonely in the future], because all the time, with a trip, a communication, an encounter - like this one today - there was a moment, one spends a good moment, makes a new acquaintance, reaches some conclusions. No....'. 


\section{Discussion and conclusion}

The aim of this study was to explore qualitatively how and to what extent religion protects older Romanian migrants from loneliness, based on in-depth interviews with 30 individuals aged 57 and older. The sample, taken in the Swiss cantons of Geneva and Vaud and in neighbouring France, included both long-settled migrants who fled the communist regime and individuals who migrated later in life for work or to be with their families. The sample did not aim to be representative, but since it is heterogeneous in terms of status at arrival, period of arrival, former economic activities, migration motives and church attendance, the data gathered through the interviews covers the diversity of older Romanian migrants.

Consistent with the literature, our findings showed a variety of ways through which religion helps participants prevent or reduce feelings of loneliness. Their faith in God and prayers sustain them with strength day-to-day and during difficult times, like life under communism and the hardships of migration. This intrinsic value of religion cuts across the different migrant types who arrived recently or long ago, and who may or may not intend to return to Romania. Through its cultural and historical meaning, the church also recreates a familiar space, thus providing the participants with a feeling of belonging. Not surprisingly, this seems particularly relevant for recently arrived migrants: the need of continuity and stability in one's life and feeling a sense of familiarity and cohesion is especially important for the period right after migration. For the same reason, former refugees established an Orthodox Romanian church upon their arrival that has nonetheless led to divisions in the long term. The church also functions as a social hub, a place of encounters that ranges from superficial contacts (recently arrived migrants) to long-lasting friendships (long-settled migrants) on which they can count for practical and emotional support. Churchgoers, however, are generally not the only support providers or receivers. While recently arrived migrants are surrounded by family and busy providing support for their children and grandchildren; because of their longer duration of stay former refugees are more able to activate and be helpful to a wider pool of social ties, including friends, neighbours and colleagues of other nationalities.

Like all studies, the present one is not without limitations. The small sample size, an unequal distribution of long-settled and recently arrived migrants, and the use of a geographically defined non-representative sample do not allow us to make any generalisable conclusions about the religion-loneliness connection among older Romanian migrants in Switzerland. Moreover, given the cross-sectional nature of the study, causal inferences regarding such a connection must be made with caution. Future research should replicate this 
study with a larger random sample across the different migrant groups - former political refugees, zero generation, family reunification, and late-in-life labour migrants - and by using a longitudinal design. It is also recommended to do similar research in other countries and among other ethnicities and religious denominations, to know more about the robustness of the relationship between religion and loneliness, two universal phenomena, in different cultural settings.

Despite its limitations, the present study nuances at least two general beliefs. Firstly, older migrants are commonly considered to be at a higher risk for loneliness because of their disadvantaged situation in several respects. Our participants are not as lonely as one could have expected, particularly thanks to the intrinsic and extrinsic benefits of their religion, as described above. In other words, in addition to health, wealth and social embeddedness in society, religion can be another important factor to increase the well-being of older migrants a factor that is too often overlooked by researchers, policymakers and practitioners. Besides religion, there are two other reasons for a relatively low level of loneliness among our participants: not having the time to constantly think about the loneliness problem, if any, because of their job, grandparenting role or other activities, and a preference for solitude. The latter has to do with Romanians' experience under communism and migration history. They always did everything by themselves, often could not rely on others - also due to a lack of trust - and this translated into a hard life under communism and after leaving Romania. Consequently, they tend to have rather low expectations of social relations that can be fulfilled with relative ease and so their loneliness threshold (Johnson and Mullins 1987) is rather high. This finding illustrates the importance of researchers and practitioners taking into account both past and present context, and, more generally, of increasing the attention paid to differences in the risk of loneliness among older migrants and factors that prevent against loneliness at various levels. Secondly, despite repeated disappointing outcomes of loneliness interventions aimed at bringing people together and improving their social network (Cattan et al. 2005; Findlay 2003; Hagan et al. 2014; Masi et al. 2011; Windle, Francis, and Coomber 2011) it is often assumed that an active problem-focused coping strategy (efforts to improve the size or quality of one's social network) is more effective in reducing feelings of loneliness than regulating one's emotions (Carstensen, Fung, and Charles 2003; Rook and Peplau 1982). Findings from our participants clearly demonstrate that, apart from its social integration role, religion includes emotion-focused approaches that can be effective in addressing the loneliness problem. Belief in and praying to God help them cope with everyday sorrows and overcome difficult moments. They avoid thinking too much about the social deficit by 
seeking distraction in other activities. We therefore make a strong plea for practitioners to pay more attention to emotion-focused coping strategies, especially if the loneliness problem is caused by circumstances beyond one's control and in cases of limited personal resources.

\section{Acknowledgements}

The fieldwork research was funded by the Swiss National Science Foundation (FNS) through the project 'Romanian Ageing Migrants in the Welfare State', number IZERZO_142219/1, coordinated by Claudio Bolzman. Ruxandra Oana Ciobanu's work is funded by the People Programme (Marie Curie Actions) of the European Union's Seventh Framework Programme (FP7/2007-2013) under REA grant agreement no 328518. She is also affiliated with the Swiss National Centre of Competence in Research LIVES 'Overcoming Vulnerability: Life Course Perspectives'. Tineke Fokkema's work is part of the 'Families in Context' project, funded by an Advanced Investigator Grant of the European Research Council (ERC, 324211). 


\section{References}

Ahmadi Lewin, Fereshteh, and Eugene Thomas. 2001. "Gerotranscendence and Life

Satisfaction: Studies of Religious and Secular Iranians and Turks.” Journal of Religious Gerontology 12 (1): 17-41.

Bolzman, Claudio, Raffaella Poncioni-Derigo, Marie Vial, and Rosita Fibbi. 2004. “Older Labour Migrants' Well Being in Europe: The Case of Switzerland.” Ageing and Society 24 (3): 411-429.

Bolzman, Claudio, Rosita Fibbi, and Marie Vial. 2006. "What To Do After Retirement? Elderly Migrants and the Question of Return." Journal of Ethnic and Migration Studies 32 (8): 1359-1375.

Bolzman, Claudio, Élisabeth Hirsch Durret, Simon Anderfuhren, Marilène Vuille, and Monique Jaggi. 2008. "Le regroupement familial des ascendants.” Retraite et Société 55 (3): $39-69$.

Bolzman, Claudio, and Helena Scott. 2010. "Exil et vieillesse: Les réfugiés agés en Europe." Diversités et citoyennetés: La lettre de l'IRFAM 22: 2-22.

Carstensen, Laura L., Helene H. Fung, and Susan T. Charles. 2003. “Socioemotional Selectivity Theory and the Regulation of Emotion in Second Half of Life." Motivation and Emotion 27: 103-123.

Cattan, Mima, Martin White, John Bond, and Alison Learmouth. 2005. "Preventing Social Isolation and Loneliness among Older People: A Systematic Review of Health Promotion Interventions." Ageing and Society 25 (1): 41-67.

Cela, Eralba, and Tineke Fokkema. 2016. "Being Lonely Later in Life: A Qualitative Study among Albanians and Moroccans in Italy." Ageing and Society. doi: 10.1017/S0144686X16000209.

Choudhry, U.K. 2001. "Uprooting and Resettlement Experiences of South Asian Immigrant Women.” Western Journal of Nursing Research 23 (4): 376-393.

Ciobanu, Ruxandra O. 2009. “A Stage Approach to Transnational Migration. Migrant Narratives from Rural Romania.” PhD diss., University of Osnabrück. https://repositorium.uni-osnabrueck.de/bitstream/urn:nbn:de:gbv:700201007306415/19/thesis_ciobanu.pdf.

de Jong Gierveld, Jenny, Suzan van der Pas, and Norah Keating. 2015. “Loneliness of Older Immigrant Groups in Canada: Effects of Ethnic-Cultural Background." Journal of CrossCultural Gerontology 30 (3): 251-268. 
de Jong Gierveld, Jenny, and Theo van Tilburg. 1999. Manual of the Loneliness Scale. VU

University Amsterdam, Department of Social Research Methodology.

Dong, XinQi, E-Shien Chang, Esther Wong, and Melissa Simon. 2012. "Perception and

Negative Effect of Loneliness in a Chicago Chinese Population of Older Adults."

Archives of Gerontology and Geriatrics 54: 151-159.

Dowd, J.J., and V.L. Bengtson. 1978. "Aging in Minority Populations: An Examination of the Double Jeopardy Hypothesis.” Journal of Gerontology 33 (3): 427-436.

Ellison, Christopher G., and Jeffrey S. Levin. 1998. "The Religion-Health Connection:

Evidence, Theory and Future Directions." Health Education \& Behavior 25 (6): 700-720.

Federal Office of Statistics, Switzerland. 2011. Table "Resident population by canton, type of

population, gender, age group, residence permit, year and nationality."

Federal Office of Statistics, Switzerland, PETRA.

Findlay, Robyn A. 2003. "Interventions to Reduce Social Isolation amongst Older People:

Where is the Evidence?" Ageing and Society 23 (5): 647-658.

Fokkema, Tineke, and Robert Naderi. 2013. "Differences in Late-Life Loneliness: A

Comparison between Turkish and Native-Born Older Adults in Germany." European Journal of Ageing 10 (4): 289-300.

Gray, Anne. 2009. “The Social Capital of Older People.” Ageing and Society 29 (1): 5-31.

Guillon, Michelle, Marie Vial, Rosita Fibbi, and Claudio Bolzman. 2001. "La famille: Une source de légitimité pour les immigrés après la retraite? Le cas des Espagnols et des Italiens en Suisse." Revue Européenne de Migrations Internationales 17 (1): 55-78.

Hagan, Robert, Roger Manktelow, Brian J. Taylor, and John Mallett. 2014. "Reducing Loneliness amongst Older People: A Systematic Search and Narrative Review." Aging \& Mental Health 18 (6): 683-693.

Hainard, François, and Maria Hämmerli. 2011. "Multiple Dimensions of the Integration Process of Eastern Orthodox Communities in Switzerland." National Research Programme 58: Religion, the State and Society. Université de Neuchâtel, Institut de sociologie. Final research report, March 2011, http://www.nfp58.ch/files/downloads/NFP58_Schlussbericht_Hainard.pdf.

Ip, David, Chi Wai Lui, and Wing Hong Chui. 2007. "Veiled Entrapment: A Study of Social Isolation of Older Chinese Migrants in Brisbane, Queensland.” Ageing and Society 27 (5): 719-738. 
Johnson, D. Paul, and Larry C. Mullins. 1987. "Growing Old and Lonely in Different Societies: Toward a Comparative Perspective.” Journal of Cross-Cultural Gerontology 2 (3): $257-275$.

Johnson, Doyle P., and Larry C. Mullins. 1989. "Subjective and Social Dimensions of Religiosity and Loneliness among the Well Elderly." Review of Religious Research 31 (1): $3-15$.

Kim, Young Sek. 2013. "Ethnic Senior Schools, Religion, and Psychological Well-Being Among Older Korean Immigrants in the United States: A Qualitative Study." Educational Gerontology 39 (5): 342-354.

King, Russell, Eralba Cela, Tineke Fokkema, and Julie Vullnetari. 2014. "The Migration and Well-Being of the Zero Generation: Transgenerational Care, Grandparenting and Loneliness amongst Albanian Older People.” Population, Space and Place 20 (8): 728738.

King, Russell, and Julie Vullnetari. 2006. “Orphan Pensioners and Migrating Grandparents:

The Impact of Mass Migration on Older People in Rural Albania.” Ageing and Society 26 (5): 783-816.

Kobayashi, Karen M., Denise Cloutier-Fisher, and Marilyn Roth. 2009. "Making Meaningful Connections: A Profile of Social Isolation and Health among Older Adults in Small Town and Small City, British Columbia.” Journal of Aging and Health 21: 374-397.

Koenig, Harold G., Michael E. McCullough, and David B. Larson. 2001. The Handbook of Religion and Health. New York: Oxford University Press.

Krause, Neal. 2008. Aging in Church: How Social Relationships Affect Health. Conshohocken, P.A.: Templeton Foundation Press.

Krause, Neal, and Keith M. Wulff. 2005. "Friendship Ties in the Church and Depressive Symptoms: Exploring Variations by Age". Review of Religious Research 46 (4): 325340.

Lee, Young-Me. 2007. “The Immigration Experience among Elderly Korean Immigrants.” Journal of Psychiatric and Mental Health Nursing 14 (4): 403-410.

Masi, Christopher M., His-Yuan Chen, Louise C. Hawkley, and John T. Cacioppo. 2011. “A Meta-Analysis of Interventions to Reduce Loneliness." Personality and Social Psychology Review 15 (3): 219-266.

Michalon, Bénédicte, and Mihaela Nedelcu. 2010. "Introduction: Histoire, constantes et transformations récentes des dynamiques migratoires en Roumanie." Revue d'études comparatives Est-Ouest 41 (4): 5-27. 
Musillo, Italo and Bolzman, Claudio (with the collaboration of Catherine Tavier). 1986. "De l'accueil à l'insertion. Les demandeurs d'asile à Genève de 1974 à 1983." Cahier numéro 8, Hospice General, Service d'information social et juridique.

Nedelcu, Mihaela. 2009. “La 'génération zéro': du sédentaire à l'acteur circulant. Effets de mobilité sur la génération des parents des migrants roumains hautement qualifiés à Toronto à l'ère du numérique." In Les circulations transnationales. Lire les turbulences migratoires contemporaines, edited by Geneviève Cortes, and Laurent Faret, 187-198. Paris: Armand Colin.

Pargament, Kenneth I. 1997. The Psychology of Religion and Coping: Theory, Research, and Practice. New York: Guilford.

Park, Hong-Jae, and Chang Gi Kim. 2013. "Ageing in an Inconvenient Paradise: The Immigrant Experiences of Older Korean People in Aotearoa New Zealand.” Australasian Journal on Ageing 32 (3): 158-162.

Perlman, Daniel, and Letita A. Peplau. 1981. "Toward a Social Psychology of Loneliness.” In Personal Relationships: Personal Relationships in Disorder, edited by R. Gilmour, and S. Duck, 31-56. London: Academic Press.

Roh, Soonhee, Kyoung Hag Lee, and Dong Pil Yoon. 2013. “General Well-Being of Korean Immigrant Elders: The Significance of Religiousness/Spirituality and Social Support.” Journal of Social Service Research 39 (4): 483-497.

Romanian Census. 2011. Table 13-2: Stable population by religion - counties, municipalities, communes. Final results. Consulted the $18^{\text {th }}$ July 2014 at www.recensamantromania.ro/wp-content/uploads/2013/07/sR_TAB_13.xls.

Rook, Karen S., and Letitia A. Peplau. 1982. "Perspectives on Helping the Lonely.” In Loneliness: A Sourcebook of Current Theory, Research and Therapy, edited by Letitia A. Peplau, and Daniel Perlman, 351-378. New York: John Wiley.

Rote, Sunshine, Terrence D. Hill, and Christopher G. Ellison. 2013. "Religious Attendance and Loneliness in Later Life." The Gerontologist 53 (1): 39-50.

Sandu, Dumitru 2005. "Emerging Transnational Migration from Romanian Villages." Current Sociology 53: 555-582.

Silveira, Ellen, and Peter Allebeck. 2001. "Migration, Ageing and Mental Health: An Ethnographic Study on Perceptions of Life Satisfaction, Anxiety and Depression in Older Somali Men in East London.” International Journal of Social Welfare 10: 209-320.

Soulard, Elodie, ed. 2013. “Les Réfugiés Agés; Invisible parmi les Invisible.” Les cahiers du social 34. Accessed on the 5th of June 2014. 
http://www.reso77.asso.fr/filemanager/files/Infos\%20par\%20structures/France\%20Terre \%20d\%27asile/130301_FTA_les_refugies_ages.pdf

Swiss Statistics, Table "Population résidante permanente et non permanente selon le canton, le sexe, l'autorisation de résidence, la classe d'âge et la nationalité." http://www.pxweb.bfs.admin.ch/Dialog/varval.asp?ma=px-f-013A01\&path=../Database/French_01\%20-\%20Population/01.3\%20\%20Migration\%20et $\% 20 \mathrm{int} \%$ E9gration/\&lang=2\&prod=01\&openChild=true \&secprod= $\underline{3}$.

Treas, Judith, and Shampa Mazumdar. 2002. “Older People in America's Immigrant Families: Dilemmas of Dependence, Integration, and Isolation." Journal of Aging Studies 16 (3): $243-258$.

Victor, Christina R., Vanessa Burholt, and Wendy Martin. 2012. "Loneliness and Ethnic Minority Elders in Great Britain: An Exploraty Study.” Journal of Cross-Cultural Gerontology 27 (1): 65-78.

Voicu, Malina, and Andreea Constantin. 2012. "Religious Revival in Romania: Between Cohort Replacement and Contextual Changes." In Transformations of Religiosity Religion and Religiosity in Central and Eastern Europe 1989-2010, edited by Gert Pickel, and Kornelia Sammet, 155-174. Wiesbaden: Springer.

Voicu, Mălina; Fosztó, László, and Sorin Gog. 2009. “Twenty Years after the Fall of Official Atheism: The Contemporary Romanian Religious Landscape. Guest Editors' Foreword.” Sociologia, 54 (2): 3-8.

Windle, Karen, Jennifer Francis, and Caroline Coomber. 2011. "Preventing Loneliness and Social Isolation: Interventions and Outcomes.” Research Briefing 39: 1-15: Social care institute for excellence.

Wu, Zheng, and Margaret Penning. 2015. "Immigration and Loneliness in Later Life." Ageing and Society 35 (1): 64-95.

Zubair, Maria, and Meriel Norris. 2015. "Perspectives on Aging, Later Life and Ethnicity: Ageing Research in Ethnic Minority Contexts.” Ageing and Society 35 (5): 897-916. Zhang, Gehui and Heying Jenny Zhan. 2009. "Beyond the Bible and the Cross: A Social and Cultural Analysis of Chinese Elders' Participation in Christian Congregations in the United States.” Sociological Spectrum: Mid-South Sociological Association 29 (2): 295317. 
Table 1. Descriptive statistics of the participants

\begin{tabular}{|c|c|c|c|c|c|c|c|c|c|c|}
\hline$\#$ & Type of migrant & Age & Gender & $\begin{array}{l}\text { Year of arrival } \\
\text { in Switzerland / } \\
\text { France }\end{array}$ & $\begin{array}{l}\text { Marital } \\
\text { status }\end{array}$ & Education & Former economic activity & $\begin{array}{l}\text { Church } \\
\text { attendance }\end{array}$ & $\begin{array}{l}\text { Loneliness scale } \\
\text { score }\end{array}$ & $\begin{array}{l}\text { Mentioned loneliness } \\
\text { during the interview }\end{array}$ \\
\hline 1 & Former refugee & 73 & $F$ & 1979 & Widowed & Nursing school & Nurse & Yes & Not lonely & Not lonely \\
\hline 2 & Former refugee & 67 & M & 1982 & Married & University & Teacher and artist & Yes & Moderately lonely & Not lonely \\
\hline 3 & Zero generation & 61 & $\mathrm{~F}$ & 2010 & Married & High school & $\begin{array}{l}\text { Romania: accountant, PR; } \\
\text { Switzerland: no work }\end{array}$ & Yes & Moderately lonely & Lonely \\
\hline 4 & Zero generation & 65 & $\mathrm{~F}$ & 2012 & Widowed & High school & Administrative work & Yes & Not lonely & Not lonely \\
\hline 5 & Former refugee & 65 & $\mathrm{~F}$ & 1978 & Married & Vocational school & $\begin{array}{l}\text { Employed by husband's } \\
\text { construction company }\end{array}$ & Yes & - & $\begin{array}{l}\text { Felt very lonely upon } \\
\text { arrival in Switzerland }\end{array}$ \\
\hline 6 & Former refugee & 76 & M & 1978 & Married & University & Local administration & Yes & Not lonely & Not lonely \\
\hline 7 & Late-in-life labour migrant & 57 & $\mathrm{~F}$ & 2007 & Widower & High school & $\begin{array}{l}\text { Romania: statistician } \\
\text { Switzerland: caregiver for elderly }\end{array}$ & Sometimes & Moderately lonely & Lonely \\
\hline 8 & Family reunification & 68 & F & 1994 & Married & University & $\begin{array}{l}\text { Romania: engineer } \\
\text { Switzerland: no work }\end{array}$ & Yes & Moderately lonely & Lonely \\
\hline 9 & Former refugee & 72 & M & 1972 & Divorced & University & Psychiatrist & Yes & - & Lonely \\
\hline 10 & Former refugee & 83 & $\mathrm{~F}$ & 1990 & Widower & $\begin{array}{l}\text { Three-year college, } \\
\text { social work }\end{array}$ & $\begin{array}{l}\text { Romania: social worker } \\
\text { Switzerland: informal work }\end{array}$ & Yes & Not lonely & $\begin{array}{l}\text { Felt lonely after husband's } \\
\text { death, now not lonely }\end{array}$ \\
\hline 11 & $\begin{array}{l}\text { Former refugee } \\
\text { Former refugee }\end{array}$ & $\begin{array}{l}75 \\
81\end{array}$ & $\begin{array}{l}\mathrm{F} \\
\mathrm{M}\end{array}$ & $\begin{array}{l}1982 \\
1981\end{array}$ & $\begin{array}{l}\text { Married } \\
\text { Married }\end{array}$ & $\begin{array}{l}\text { Technical college } \\
\text { University }\end{array}$ & $\begin{array}{l}\text { Technical designer } \\
\text { Low-skilled jobs }\end{array}$ & $\begin{array}{l}\text { Rarely } \\
\text { Rarely }\end{array}$ & Not lonely & Not lonely \\
\hline 12 & $\begin{array}{l}\text { Came under communism (with } \\
\text { passport to settle abroad) }\end{array}$ & 80 & $\mathrm{~F}$ & 1973 & Married & High school & Secretariat and accounting & Sometimes & Not lonely & Not lonely \\
\hline 13 & Former refugee & 71 & M & 1976 & Married & University & Entrepreneur, IT & Yes & Not lonely & Not lonely \\
\hline 14 & Zero generation & 61 & $\mathrm{~F}$ & $\begin{array}{l}2009 \text { temporary; } \\
\text { since } 2011 \text { more } \\
\text { permanently }\end{array}$ & Married & Chemistry college & $\begin{array}{l}\text { Romania: chemist } \\
\text { Switzerland: no work }\end{array}$ & Yes & Not lonely & Not lonely \\
\hline 15 & Former refugee & 72 & $\mathrm{~F}$ & 1982 & Married & University & Nurse in a home for the elderly & Yes & Not lonely & Not lonely \\
\hline 16 & Family reunification & 62 & $\mathrm{~F}$ & 2005 & Widower & Vocational school & $\begin{array}{l}\text { Romania: worker } \\
\text { Switzerland: no work }\end{array}$ & Yes & Moderately lonely & Moderately lonely \\
\hline 17 & Former refugee & 73 & $\mathrm{~F}$ & 1984 & Divorced & High school & $\begin{array}{l}\text { Babysitter, stopped working for } \\
\text { health reasons }\end{array}$ & Yes & Moderately lonely & $\begin{array}{l}\text { Moderately lonely } \\
\text { (discreet in her attitude) }\end{array}$ \\
\hline 18 & Former refugee & 70 & $\mathrm{~F}$ & 1982 & Married & University & Architect & Yes & Moderately lonely & Not lonely \\
\hline 19 & Former refugee & 67 & $\mathrm{~F}$ & 1972 & Married & $\begin{array}{l}\text { High school and } \\
\text { Art school }\end{array}$ & Secretary & Yes & Not lonely & Not lonely \\
\hline 20 & Former refugee & 67 & $\mathrm{~F}$ & 1971 & Married & University & Psychologist & Yes & Not lonely & Not lonely \\
\hline 21 & Former refugee & 92 & M & 1971 & Married & University & Doctor & Yes & Not lonely & Not lonely \\
\hline 22 & Former refugee & 70 & $\mathrm{~F}$ & 1986 & Widower & -- & Nurse in a home for the elderly & Yes & Moderately lonely & Not lonely, nostalgic \\
\hline 23 & Former refugee & 81 & $\mathrm{M}$ & 1971 & Married & University & $\begin{array}{l}\text { Architect, entrepreneur (still } \\
\text { working) }\end{array}$ & No & Not lonely & Not lonely \\
\hline 24 & $\begin{array}{l}\text { Former refugee } \\
\text { Former refugee }\end{array}$ & 65 & $\begin{array}{l}\mathrm{F} \\
\mathrm{M}\end{array}$ & $\begin{array}{l}1974 \\
1974\end{array}$ & $\begin{array}{l}\text { Married } \\
\text { Married }\end{array}$ & $\begin{array}{l}\text { College for nurses } \\
\text { University }\end{array}$ & $\begin{array}{l}\text { Nurse } \\
\text { Granhic desioner for a iournal }\end{array}$ & $\begin{array}{l}\text { No } \\
\text { No }\end{array}$ & Moderately lonely & Not lonely \\
\hline 25 & $\begin{array}{l}\text { Former refugee } \\
\text { Former refugee }\end{array}$ & $\begin{array}{l}80 \\
66\end{array}$ & $\begin{array}{l}\mathrm{M} \\
\mathrm{F}\end{array}$ & $\begin{array}{l}1974 \\
1982\end{array}$ & $\begin{array}{l}\text { Married } \\
\text { Married }\end{array}$ & $\begin{array}{l}\text { University } \\
\text { University }\end{array}$ & $\begin{array}{l}\text { Graphic designer for a journal } \\
\text { Architect }\end{array}$ & $\begin{array}{l}\text { No } \\
\text { Rarely }\end{array}$ & Not lonely & Not lonely \\
\hline & Former refugee & 72 & M & 1982 & Married & University & Engineer & Rarely & & \\
\hline 26 & $\begin{array}{l}\text { Came under communism (family } \\
\text { reunification, Swiss origin) }\end{array}$ & 72 & $\mathrm{~F}$ & 1980 & Married & University & Engineer & Sometimes & Not lonely & Not lonely \\
\hline 27 & Former refugee & 69 & M & 1981 & Married & University & Engineer & Rarely & Not lonely & Not lonely \\
\hline
\end{tabular}


